Novikova Olha, senior lecturer of the department of Economics and entrepreneurship, Sumy National Agrarian University, Ukraine

ORCID ID: 0000-0002-6999-9268

e-mail: novikova.css@gmail.com

\title{
Principles and Priorities of Labor Potential Management at the Enterprise
}

Abstract. Introduction. Labor potential constitutes an integral, important part of the potential of the company, being an attribute parameter, which predetermines the competitive success of the company either by accelerating it or leading to a complete failure in case of poor management.

Purpose. to redefine the definition and role of the labor potential in the company, their characteristics, and the main principles of development. Clarify the most essential characteristics of the employees, who are the key elements of labor potential for the employer, and preferences of the management to different methods of treating them in case of poor performance.

Results. Major characteristics of the labor potential were outlined. According to the survey provided at SMEs in Ukraine, employers put higher rank to professional skills, experience in the company, loyalty and dedication, prior experience in the sphere, qualifications obtained through formal education, ability to work in a team and cooperate. Less importance was assigned to psychological traits, temper, physical characteristics, health, physical strength, and marital status, family, moral principles. In the case of poor performance, $16 \%$ of the managers declared their desire to fire the worker but the real rate of termination of the employment amounted to $31.6 \%$ in 2018.

Conclusions. Labor potential of the enterprise is a critical element of the company's potential due to the unique role in the economic activity, it can easily facilitate the increase of profit or otherwise lead a company to bankruptcy. It depends on a range of objective and subjective factors which include personal characteristics of the workers and their ability to cooperate and are strongly connected with material and information supply. Many of the components can be enhanced without the change of personnel composition through the training and self-improvement. But this will only happen if the company follows the correct principles and set distinct goals. Nevertheless, in the case of poor performance managers will consider layoffs with subsequent recruitment as a possible option with more than $30 \%$ of employees being fired during the year on average. Employee retention should be considered as strategic imperative and resources should be allocated for that.

Keywords: labor potential; human resource; turnover ratio; enterprise potential; personnel characteristics; principles of labor potential formation.

\section{УдК 331.108: 658.336}

Новікова О. С., старший викладач кафедри економіки та підприємництва, Сумський національний аграрний університет, м. Суми, Україна

\section{Принципи та пріоритети управління трудовим потенціалом на підприємстві}

Анотація. Трудовий потенціал підприємства є найважливішим елементом потенціалу підприємства завдяки унікальній ролі в економічній діяльності, він може легко сприяти збільшенню прибутку або ж призвести підприємство до банкрутства. Метою дослідження є уточнення визначення та ролі трудового потенціалу на підприємстві, його характеристики та основних принципів розвитку, виділення найважливіших рис працівників, які $\epsilon$ ключовими елементами трудового потенціалу для роботодавця, та уподобання керівництва щодо різних методів поводження з працівниками у разі їх недостатньої продуктивності. Систематизовано об'єктивні та суб'єктивні фактори, які включають особистісні характеристики працівників та їх здатність до співпраці і тісно пов'язані з матеріальноінформаційним забезпеченням. Зәідно з опитуванням, проведеним серед малих та середніх підприємств в Україні, роботодавці найбільше цінують професійні навички, досвід роботи в компанії, лояльність та відданість, попередній досвід роботи у цій галузі, кваліфікацію, здобуту завдяки формальній освіті, вміння працювати в команді та співпрацювати. Менше значення було відведено таким рисам: психологічні особливості, характер, фізичні особливості, сила, здоров'я, сімейний стан, моральні принципи. Багато компонентів трудового персоналу можна вдосконалити без зміни складу персоналу шляхом навчання та самовдосконалення, але це відбувається лише в тому випадку, якщо компанія дотримується необхідних принципів його розвитку і встановлює чіткі стратегічні та середньострокові цілі. у випадку поганої роботи 16\% керівників заявили про бажання звільнити працівника, але справжній відсоток звільнення стосовно середньооблікового числа працівників склало 31,6\% у 2018 році. Потужність трудового потенціалу організації залежить від цілого ряду об'єктивних і суб'єктивних факторів, які включають особистісні характеристики працівників та їх здатність до співпраці $і$ тісно пов'язані з матеріально-інформаційним забезпеченням. Підприємці добре усвідомлюють провідну роль трудового потенціалу в досягненні своїх цілей $i$ заявляють про бажання утримувати працівників на робочому місці, що має ряд переваг і має розглядатись як стратегічний імператив і завжди потребує виділення додаткових ресурсів.

Ключові слова: трудовий потенціал; людські ресурси; коефіцієнт оборотності персоналу; потенціал підприємства; характеристики персоналу; принципи формування трудового потенціалу. 
Formulation of the problem. At present, the problems of rational use of labor potential, its development as a factor of enterprise competitiveness have not yet found their distinct place in the system of the general management of the enterprise and remain at the responsibility of human resource management. Major principles of its formation and utilizing may need proper defining and priorities should be set.

However, it is already safe to say that together with the information potential, which is also closely intertwined with other types of potential, labor potential also constitutes an integral, important part of any of them, being an attribute parameter, which predetermines the competitive success of the company either by accelerating it or leading to a complete failure in case of poor management.

Analysis of recent research and publications. Labor potential management has already been developed and analyzes in the works of Romanov A., Cvetkova I., Davydiuk T., however, the labor potential of the company was often analyzed from the perspective of welfare and social production, while private needs of the entrepreneurs and their opinion about the development of labor potential have often been neglected [1-3].

Formulation of research goals. The purpose of this article is to redefine the definition, and role of the labor potential in the company, their characteristics and the main principles of development. Clarify the most essential characteristics of the employees, who are the key elements of labor potential for the employer, and preferences of the management to different methods of treating them in case of poor performance.

Outline of the main research material. Mainly enterprise potential may be considered as an aggregate of the company's resources and facilities, which can be potentially used to reach the goals of the enterprise. Others point out the ability of the enterprise's system of resources and competencies to produce results for stakeholders through the implementation of business processes [4, p.125]. Even more, it is described by Romanov A. [1, p.17] to be a result of economic and production relations between economic entities. Despite minor discrepancies in the meaning, it is undoubtful that the economic potential of the company should include both tangible, and also intangible assets, and market advantages which may bring economic benefits.

This approach to the identification of economic potential with a set of available resources is a prerequisite for the emergence of components of economic potential: investment potential, production potential, labor potential, natural resource potential [1, p.24].
Being one of the most important for the company and combined with all other kinds of potential, labor potential requires careful consideration and a very specific approach as it can either boost the economic productivity and efficiency of all other kinds of potential or lead the company to bankruptcy and devaluate all the investments if being ill-treated.

There is an essential difference between labor potential and just human resource of the company regarding the purposefulness of using it for the achievement of the goals of the enterprise, strong connection between the elements and dependence on the other kinds of potential, which includes supplies and working environment [4, p.127].

Labor potential can be defined at macro, micro, and unit levels. At the macro level we speak about the aggregate potential of all population of the region with their demographic characteristics, literacy and education level, customs, and traditions strongly connected with desire and attitude to work. It can only be developed through demographic policy, healthcare, improvement in the education system.

The unit level is a labor potential of a person with their particular physical and mental condition, abilities and talents, personal skills and qualifications, acquired through formal and informal training and experiences. It also strongly depends on the motivation and attitude to work.

The labor potential of the enterprise is one of the most important components of its economic potential. In a very materialistic way, labor potential at the enterprise level can be measured as a totality of the company's employees, obliged to work for a legally established period with publicly acceptable intensity [5]. But it definitely goes far beyond this simplified definition as each employee can be characterized by the unique set of features that determine his ability to create value. These features include both objective and subjective factors [6]. Worker productivity over a given period of time is a function of innate ability, the level of effort, and the environment (the weather, general business conditions, or the actions of other employees). In the following chart (Pic.1) main factors, affecting the labor potential of the company are presented together with the influence of other kinds of potential. As one can see, some components of it can be affected by the management and thus improved while the other could be modified only through the changes in the staff composition. This possibility presents many differences from the macro and unit labor potential as they can only be modified through the development and improvement of present workers and population. 


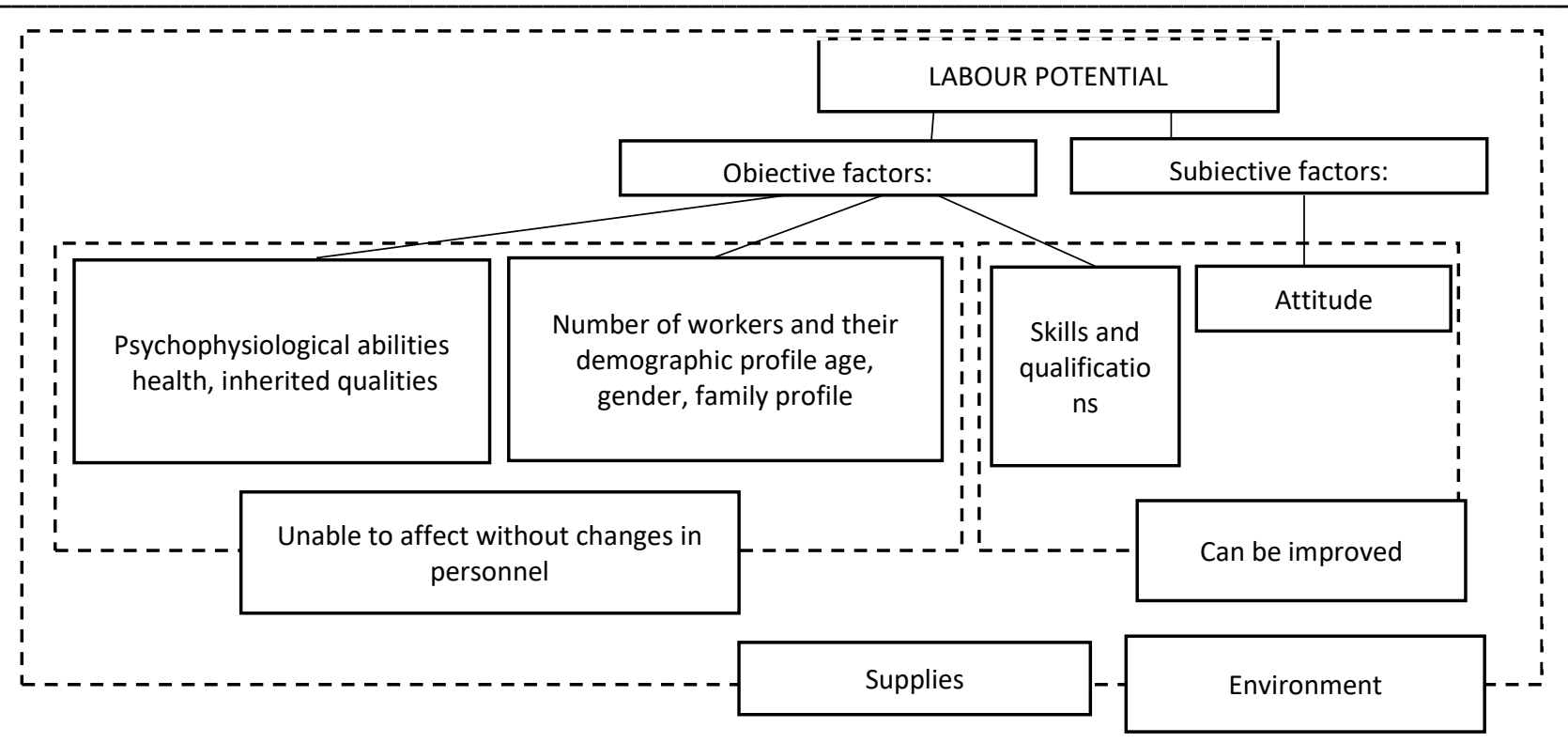

Figure 1 - Factors affecting the formation of the labor potential of the company

Source: author's own research based on [1,5]

We conducted research on the most important characteristics, considered by the managers when hiring a worker and taking a layoff decision at 95 SMEs in Ukraine. It was proposed to range the factors which define the value of every particular employee for the company with 8 for the most important and 1 - for the least valuable characteristic. Afterwards, an average rank was determined. According to the results, employers valued most highly professional skills and experience in the company and less highly - personal psychological and physical characteristics. The least important among the others was marital status, moral principles and family connections. Surprisingly the ability to work in the team was more important than all the other psychological traits with an average rank of 4.8 compared to 4.6. Experience in the company, loyalty and dedication was also more important than prior experience in the sphere and even qualifications obtained through formal education.

Table 1. Summarized results of the questionnaire for the evaluation of the most important characteristics of personnel

\begin{tabular}{|l|c|}
\hline Characteristic & Rank \\
\hline Professional skills & 5.4 \\
\hline Experience in the company, loyalty and dedication & 5.2 \\
\hline Prior experience in the sphere & 5.1 \\
\hline Qualifications obtained through formal education & 4.9 \\
\hline Ability to work in a team and cooperate & 4.8 \\
\hline Psychological traits, temper & 4.6 \\
\hline Physical characteristics, health, physical strength & 3.5 \\
\hline Marital status, family, moral principles & 2.5 \\
\hline
\end{tabular}

Source: author's own research based on $[7,8]$

Labor potential management includes evaluation, optimizing, development of the human resource of the company together with an instant connection with the other kinds of potential. It should also incorporate the stages of determining the need for labor and planning, identifying parameters for the employees, during recruitment, placing worker within the company and possible change of his duties and responsibilities, development and adjustment through corresponding kinds of training, stimulate the development of the professional and personal skills.

Another important aspect is personnel appraisal, measuring the efficiency of human resource utilization in the company, finding ways to improve this indicator and business efficiency. Chasing for the perfect employees one should not forget about the cost of labor. Being underpaid will demotivate workers and reduce their productivity while overpaying will reduce business efficiency and may lead to bankruptcy $[9,10]$. If some work might be effectively performed by a lower-paid worker this should remain a priority. Managing labor potential should include measures to secure workers with preferable characteristics while setting clear goals for those, who may improve.

Based on $[2,9,10]$ some of the principles of human resource management have been developed:

1) Maximized economic effect. Every element of human potential should bring maximal outcome for the 
company through correct work placement and providing sufficient motivation.

2) Equity. No preference should be given to anyone based on gender, race, religious beliefs or the welfare status.

3) Involvement. The most productive workers do not slavishly follow the orders but take the initiative and suggest better ways to promote the interests and achieve the goals of the business. Better involvement in the process of decision-taking enhances loyalty and dedication to work.

4) Proper selection. During the recruiting process, workers should be selected properly and parameters must be carefully set in order to minimize wrong placement and reduce the risk of wasting recruitment funds or inflated expectations of the candidate.

5) Considering the social roles, i.e. role in the family and social group determines some essential behavioral patterns and participation in the process of work.

6) Providing diverse activities. Providing the possibility to use worker in different roles increases chances to uncover the potential of each individual and find the best application of it. This can also improve the results of the personnel appraisal and make it more reliable by identifying features independent from the functions at work.

7) Providing a possibility for personal development and stimulating. It will subsequently increase the labor potential of the individual and the company especially if cooperation and information exchange is appreciated in the group. Nevertheless, we should never forget that targeted personal development should correspond to the functions performed within the organization because of the increased risks of brain exodus if combined with relatively low compensation.

8) Proper utilization of enhanced abilities will create conditions for a pay rise and secure the employees to the company. This principle should always be followed in companies of all sizes if personnel turnover is not desirable.

9) Setting clear goals based on strategic planning. Clear goals must be set and considered while creating plans for the development of personnel. If such long and middle-term planning is done properly it will help to discover reserves within the company, loyal to the company and familiar with internal processes. It will also reduce turnover because of unexpected changes in corporate policy.

10) Flexibility. Different factors may affect labor potential and proper management should allow for the possible frictions in the personnel or job modifications if a worker develops his skills and eager to take a more challenging position.

11) Proper supplies. A substitution between the labor and capital is possible but better results may be achieved and productivity will be maximized when labor is equipped properly with appropriate tools and with the development of human potential technical supply must also improve and allow for complete use of enhanced productivity.

12) The scientific approach to personnel appraisal, using vast data range, correct methodic for evaluating the performance, relevant and compatible with the goals of the company will help to make proper managerial decisions.

Following these principles will facilitate the complete use and development of the labor potential of the company. Although most companies claimed that they try to minimize personnel turnover, it cannot be completely avoided. Despite a reasonable and scientific approach, it is sometimes recommended to allow some frictions in the personnel. But nevertheless, these changes should be minimized if other options are available as the workforce are rather sensitive to the layoffs [8].

A survey has been carried out among the SMEs in the region regarding their attitude to the improvement in the human resource structure through layoffs and subsequent hiring of better more qualified workers.

We assessed the likeliness to terminate employment in case of poor performance or consider alternative actions. A yes/no scale was used to estimate the possibility of replacing the worker if he fails to satisfy the expectations of the management and investment in the development of their potential through extra training at the expense of the company. According to the results, $16 \%$ of managers preferred to substitute the employee with a better one and $21 \%$ even considered the possibility to pay for their training which proves the understanding by the management of the specific nature of the human resource.

This is also confirmed by the ranking of the actions of management in case of poor performance. Employers would first use verbal reprimands, training, and trial period, and only after that may consider a reduction in position or layoff. Very few managers considered the possibility of a pay rise as an incentive to work better and it is mainly pointed out that higher salaries should be a motivation for better workers only.

Despite the fact that entrepreneurs claimed to dislike layoff as a possible solution for the low-performance problem and use other methods of stimulation instead, they still widely use this way of improving the labor potential of the company. According to recent statistics in 2018 31.6\% of registered workers have been fired, and mostly it was not connected with the reduction of the number of jobs. This rate has grown since 2014, which was $30.3 \%$ at that time. As for the rate of admission, it is smaller and amounted to 29.2 in 2018 but it has considerably grown from $22.8 \%$ in 2014 . 
Електронне наукове фахове видання з економічних наук “Modern Economics», №2 1 (2020), 155-159 https://modecon.mnau.edu.ua | ISSN 2521-6392

Table 2. Summarized results of the questionnaire for the evaluation of the possible response of managers to employee's poor performance

\begin{tabular}{|l|c|}
\hline \multicolumn{1}{|c|}{ Question } & Percentage of respondents agreeing \\
\hline Would you prefer to replace the wrong worker rather than try to develop his skills & $16 \%$ \\
\hline Do you consider the possibility to pay for extra training for you workers & $21 \%$ \\
\hline If a worker doesn't perform as expected would you rather: & $\begin{array}{c}\text { Average rank } \\
\text { (6- the highest, } 1 \text { - the lowest) }\end{array}$ \\
\hline Use verbal reprimand & 4,5 \\
\hline Provide extra training & 4,2 \\
\hline Put them on trial period & 3,8 \\
\hline Reduction in position & 3,2 \\
\hline Layoff & 2,8 \\
\hline Consider the possibility of pay rise & 2,5 \\
\hline
\end{tabular}

Source: author's own research based on $[7,8,11]$

Table 3. The rate of admission and employment termination in Ukraine for all reasons in all kinds of enterprises.

\begin{tabular}{|l|c|c|c|c|c|}
\hline & 2014 & 2015 & 2016 & 2017 & 2018 \\
\hline The rate of admission & 22.8 & 24.0 & 26.1 & 30.5 & 29.2 \\
\hline The rate of termination & 30.3 & 30.2 & 29.2 & 31.8 & 31.6 \\
\hline
\end{tabular}

Source: State Statistics Service of Ukraine [12]

Based on stated above we can make a conclusion that in spite of being willing to keep the personnel unchanged managers may substitute on average $30 \%$ of their employees during the year and this rate is growing which is similar to American statistics [13].

Conclusion. Labor potential of the enterprise is a critical element of the company's potential due to the unique role in the economic activity, it can easily facilitate the increase of profit or otherwise lead a company to bankruptcy. It depends on a range of objective and subjective factors which include personal characteristics of the workers and their ability to cooperate and are strongly connected with material and information supply. Many of the components can be enhanced without the change of personnel composition through the training and self-improvement. But this will only happen if the company follows the correct principles and set distinct goals. Nevertheless, in the case of poor performance managers will consider layoffs with subsequent recruitment as a possible option with more than $30 \%$ of employees being fired during the year on average. Employee retention should be considered as strategic imperative and resources should be allocated for that.

\section{References:}

1. Romanov, A. P. (2012). Upravlenie jekonomicheskim potencialom organizacii. Tambov : Izd-vo FGBOU VPO «TGTU» [in Russian].

2. Cvetkova, I. I. (2012). Osnovnye principy razvitija trudovogo potenciala regiona. Jekonomika i upravlenie, (3), 41-46 [in Russian].

3. Davydiuk, T. V. (2009). Trudovi resursy, trudovyj potentsial, robocha syla, liuds'kyj kapital: vzaiemozviazok katehorij. Visnyk ZhDTU, 1 (47) [in Ukrainian].

4. Kravchenko, I. M. (2012). Analiz katehorii «trudovyj potentsial» v konteksti katehorij «robocha syla», «liuds'kyj potentsial», «liuds'kyj kapital» ta "trudovi resursy». Humanitarnyj visnyk Zaporiz'koi derzhavnoi inzhenernoi akademii, 51, 124-131 [in Ukrainian].

5. Asaliev, A. M., Mirzabalaeva, F. I., \& Alieva, P. R. (2016). Razvitie trudovogo potenciala. PR-M.: NIC INFRA-M [in Russian].

6. Johnstone, S., \& Wilkinson, A. (2017). The Potential of Labor-Management Partnership: A Longitudinal Case Analysis. British Journal of Management, 29(3), 554-570. doi:10.1111/1467-8551.12240.

7. Ivanova, A. A. (2018). Sovremennye principy i podhody k upravleniju personalom dlja obespechenija jeffektivnogo ispol'zovanija trudovogo potenciala organizacii. Molodoj uchenyj, 40 (226), 132-136 [in Russian].

8. Allinger, R., Erichsen, P., \& Beckers, K. (2014) Performance and Potential Management. Dos and Don'ts in Human Resources Management, 61-63. doi:10.1007/978-3-662-43553-3_20.

9. Maximizing Human Potential Within Organizations: Learning the Science Behind Talent Management (2013). PsycEXTRA Dataset. doi:10.1037/e520082013-001.

10. Williamson, D. (2011). Mining for hidden human potential. Human Resource Management International Digest, $19(7)$, 3-8. doi:10.1108/09670731111175498.

11. Sakhnenko, O. (2020). Management of the enterprise's human potential development. Efektyvna Ekonomika, (5). doi:10.32702/23072105-2020.5.81 [in Ukrainian].

12. Pratsia Ukrainy u 2018 rotsi. Statystychnyj zbirnyk. Kyiv. TOV «Buk-druk», 2019. 242 p. [in Ukrainian].

13. Mahan, T. F., Danny, N. (2019) Retention report 2019. Work institute. Retrieved from: https://info.workinstitute.com/hubfs/2019\%20Retention\%20Report/Work\%20Institute\%202019\%20Retention\%20Report\%20final-1.pdf 